\title{
Effect of using internal teat sealant with or without antibiotic therapy at dry-off on subsequent somatic cell count and milk production
}

\author{
Sinead McParland, ${ }^{1 *}$ P. G. Dillon, ${ }^{1}$ J. Flynn, ${ }^{1}$ N. Ryan, ${ }^{2}$ S. Arkins,${ }^{3}$ and A. Kennedy ${ }^{2}$ \\ ${ }^{1}$ Teagasc, Animal \& Grassland Research and Innovation Center, Moorepark, Fermoy, Co. Cork, P61 C996, Ireland \\ ${ }^{2}$ Department of Agriculture, Food and the Marine, Agriculture House, Kildare Street, Dublin 2, D02 WK12, Ireland \\ ${ }^{3}$ Faculty of Science and Engineering, University of Limerick, Co. Limerick, V94 C61W, Ireland
}

\section{ABSTRACT}

The objective of this study was to assess the effect of treating cows with teat sealant only compared with antibiotic plus teat sealant at drying off on weekly somatic cell count, potential intramammary infection, and milk production across the entire subsequent lactation. In 3 research herds in the south of Ireland, cows with SCC that did not exceed 200,000 cells/mL in the previous lactation (LowSCC) were randomly assigned to 1 of 2 treatments at drying off: internal teat sealant alone (ITS) or antibiotic plus teat sealant $(\mathrm{AB}+\mathrm{ITS})$. Cows with SCC that exceeded 200,000 cells $/ \mathrm{mL}$ in the previous lactation were treated with $\mathrm{AB}+\mathrm{ITS}$ and included in the analyses as a separate group (HighSCC). Weekly individual animal composite SCC records were available for 654 cow lactations and were transformed to somatic cell scores (SCS) for the purpose of analysis. Data were divided into 3 data sets to represent records obtained (1) up to 35 DIM, (2) up to 120 DIM, and (3) across the lactation. Foremilk secretions were taken from all quarters at drying off, at calving, 2 wk after calving, and in mid-lactation and were cultured to detect the presence of bacteria. The LowSCC cows treated with ITS alone had higher daily milk yield $(0.67 \mathrm{~kg} / \mathrm{d})$ across lactation compared with LowSCC cows treated with $\mathrm{AB}+\mathrm{ITS}$. The LowSCC cows treated with ITS alone had higher SCS in early, up to mid, and across lactation compared with LowSCC cows treated with AB+ITS. We detected no difference in weekly SCS of LowSCC cows treated with ITS alone and SCS of HighSCC cows. The least squares means back-transformed SCC across lactation of the LowSCC cows treated with ITS alone, LowSCC cows treated with $\mathrm{AB}+\mathrm{ITS}$, and HighSCC cows were $41,523,34,001$, and 38,939 cells $/ \mathrm{mL}$ respectively. The odds of LowSCC cows treated with ITS alone having

Received June 12, 2018.

Accepted January 9, 2019.

*Corresponding author: sinead.mcparland@teagasc.ie bacteria present in their foremilk across lactation was 2.7 (95\% confidence interval: 1.91 to 3.85$)$ and $1.6(1.22$ to 2.03) times the odds of LowSCC cows treated with $\mathrm{AB}+\mathrm{ITS}$ and of HighSCC cows treated with AB+ITS, respectively. In this study, Staphylococcus aureus was the most prevalent pathogen isolated from the population. Recategorizing the threshold for LowSCC cows as $\leq 150,000$ cells $/ \mathrm{mL}$ or $\leq 100,000$ cells $/ \mathrm{mL}$ in the previous lactation had no effect on the results. The results indicate that herds with good mastitis control programs may use ITS alone at dry-off in cows with SCC $<200,000$ cells $/ \mathrm{mL}$ across lactation with only a small effect on herd SCC.

Key words: teat sealant, dry-off, intramammary infection, mastitis control

\section{INTRODUCTION}

Mastitis is the predominant reason for antibiotic use in the dairy industry (Heringstad et al., 2000). Public concern over the use of antibiotics is rising, especially as it relates to antibiotic usage in agriculture and the implications for antimicrobial resistance (Prestinaci et al., 2015). In response, scientists and veterinary organizations have questioned the use of dry-cow antibiotics in cows with low SCC or in cows with no IMI at drying off (Cameron et al., 2014). A recent analysis of antibiotic use at dry-off across 1,657 Austrian dairy farms showed that only $31.3 \%$ of cows on those farms were dried off using antibiotics (Wittek et al., 2018). In Ireland, however, dry-cow antibiotic therapy remains a standard part of mastitis control and is used on almost $100 \%$ of cows (More et al., 2017). It is used both therapeutically (to treat infections present at the end of lactation) and prophylactically (to prevent new infections during the dry period). However, dry-cow therapy is only one critical component of mastitis control.

During the dry period, a keratin plug forms in the teat canal (Paulrud, 2005) and acts as a natural defense mechanism to protect against microbial infections. However, this natural protective mechanism is not al- 
ways effective. Internal teat sealants that mimic the natural keratin plug can be infused into the teat canal at drying-off (Meaney, 1977). Cameron et al. (2014) showed no difference in the likelihood of contracting an IMI during the dry period when cows were selectively treated with either antibiotic plus teat sealant or internal teat sealant alone. Bradley et al. (2010) showed no difference in the likelihood of contracting mastitis between ipsilateral quarters treated with internal teat sealant and antibiotic and those treated with teat sealant alone. However, the effects of treatment with antibiotic plus teat sealant versus teat sealant alone on subsequent mid- to late-lactation mastitis and SCC have not been studied; some studies investigated the effects of treatment up to 100 DIM (Bradley et al., 2010) or to 120 DIM (Cameron et al., 2014). Rabiee and Lean (2013) undertook a meta-analysis of the effect of teat sealant products on IMI, mastitis, and SCC and concluded that further studies on the impact of the use of teat sealants alone on SCC are required. The objective of this study was to quantify the effect of administration of an internal teat sealant alone compared with treatment with antibiotic plus teat sealant at drying off on subsequent SCC, potential infection, and milk production across the entire subsequent lactation in spring-calving, grazing dairy cows.

\section{MATERIALS AND METHODS}

This study was approved by the Teagasc Animal Ethics Committee and all procedures were authorized and carried out in accordance with the Health Products Regulatory Authority (HPRA) of Ireland.

\section{Data}

Multiparous cows from 3 research herds operated by the Teagasc Animal and Grassland Research and Innovation Center and located in Co. Cork, Ireland, were enrolled in the study. The study was undertaken in the Teagasc Clonakilty research herd from 2015 to 2017, and in the Teagasc Moorepark and Teagasc Curtins research herds in 2017. These herds were chosen for this study because of their historically low bulk tank SCC; herd SCC remained below 200,000 cells/mL for the majority of the year before the trial. Bulk tank SCC exceeded 200,000 cells/mL only in January ( $\mathrm{n}=$ 2 ) and February $(n=2)$, coinciding with the onset of calving in the research herds. Throughout the period of the present study, all cows were on concurrent studies investigating the effects of alternative grass-based diets on animal performance. All animals were spring calving (i.e., calved between mid-January and April, inclusive) and were housed over the dry period in group housing that had individual cubicles available for all cows as well as automatic scrapers. Cubicles were cleaned and lined daily. Only cows that were dried-off between November and December before calving were considered for this study.

Throughout lactation, individual animal daily milk yield and milk fat and protein composition were recorded, once weekly, using consecutive evening and morning milk samples; individual animal SCC was recorded once weekly on the morning milk sample using a Foss FT 6000 Milkoscan and Fossomatic FC (Foss, Hillerød, Denmark).

\section{Treatment Administration}

Eligibility for inclusion in the experiment was determined 4 to $6 \mathrm{wk}$ before drying-off. Cows were deemed eligible if SCC had not exceeded 200,000 cells/mL at any time during the previous lactation and they had not presented with a clinical case of mastitis during the previous lactation (LowSCC). Eligible LowSCC cows were blocked according to expected calving date, experimental treatment (on the concurrent experiment), and parity number. Within block, LowSCC cows were randomly administered 1 of 2 treatments: internal teat sealant (Boviseal, Bimeda, Dublin, Ireland; www .bimeda.ie) alone (ITS) or a cephalonium-based antibiotic treatment (Cepravin Dry Cow Intramammary Suspension, MSD Animal Health, Kenilworth, NJ; www.msd-animal-health.co.in) followed by internal teat sealant (AB+ITS). Cows that had a SCC >200,000 cells $/ \mathrm{mL}$ or presented a case of clinical mastitis in the previous lactation were administered $\mathrm{AB}+\mathrm{ITS}$ and included in all analyses as a separate group (HighSCC).

Before treatment administration, strict teat disinfection procedures were implemented. The teat end and orifice were scrubbed with cotton wool soaked in methylated spirits until no trace of dirt could be identified on the cotton wool. Antibiotic therapy was administered to selected (AB+ITS and HighSCC) cows by gently inserting the nozzle of the treatment partially into the teat canal; the contents were infused and the teat was massaged. Teat sealant was administered to all animals similarly (following administration of antibiotic treatment in cows that were receiving both treatments); however, the teat was not massaged and the base of the teat was held throughout treatment administration. All teats were sprayed immediately after treatment with commercial teat spray, and treated animals were subsequently left to stand for $15 \mathrm{~min}$ before returning to cubicles.

The entire data set included 131, 128, and 395 cows that calved in 2015,2016, and 2017, respectively, of which 67,69 , and 177, were LowSCC, respectively. 


\section{Quarter-Level Sampling}

Individual quarter secretions of cows were taken in an aseptic manner on 4 occasions: (1) at dry-off after enrollment, (2) at first milking post-calving, (3) $14 \mathrm{~d}$ after calving, and (4) in mid lactation (approximately 120 DIM). Samples were obtained by trained personnel. Before sample collection, each teat was washed and dried where necessary and scrubbed with a cotton swab soaked in methylated spirits; quarters were cleaned from front to rear. The first 3 squirts of milk were discarded to remove contaminated milk and material from the tip of the teat. Samples were subsequently collected from rear to front into sterile capped $30-\mathrm{mL}$ tubes color coded to represent each quarter. Samples were refrigerated and analyzed within $24 \mathrm{~h}$ of collection.

All foremilk secretions had SCC quantified and were cultured for the presence of bacteria. The SCC of the first postcalving milk sample was estimated by trained personnel using the California Mastitis Test (CMT; Ferronatto et al., 2018) because of the viscosity of the colostrum. The CMT is a subjective test of SCC using results of negative, trace, weak positive, distinct positive, and strong positive (Schalm and Noorlander, 1956), which were numbered 1 (negative) to 5 (strong positive) for the purposes of this study. The SCC of all other quarter-level secretions were quantified using a Bentley Somacount 300, which uses a proprietary method of laser-based flow cytometry to quantify somatic cells (Bentley Instrument Inc., Chaska, MN).

Foremilk samples were cultured to isolate and identify bacteria using blood agar plates. The blood agar plate was divided into 4 equal sections and clearly identified with cow identification and quarter. Samples were plated using $10-\mu \mathrm{L}$ aseptic loops, incubated at $37^{\circ} \mathrm{C}$, and examined after 18 to $24 \mathrm{~h}$ for growth morphologic features such as colony size, shape, color, and hemolytic characteristics. Any bacterial growth on the blood agar plates was considered to indicate the presence of bacteria. Samples with more than 2 bacterial species present were considered contaminated samples and discarded from analyses.

\section{Data Analysis}

Somatic cell count was transformed to SCS by taking the logarithm to the base 10 of SCC (after adding a shift parameter of 1). Parities $>3$ were grouped together for analysis. Cow breed composition as obtained from the national database (http://www.icbf.com) was redefined for the present study as the proportion of Holstein-Friesian, Jersey, Norwegian Red, and "other." Coefficients of heterosis and recombination loss were calculated for each cow according to VanRaden and Sanders (2003).

Data Sets. Individual animal SCS data were available for each week of lactation; 3 data sets were generated: (1) the first 3 records of SCS taken within the first 35 DIM were retained for analysis; (2) the first $120 \mathrm{~d}$ of lactation wherein weekly records $(\mathrm{n}=12-15)$ of SCS up to 120 DIM were retained for analysis; and (3) the complete lactation wherein all SCS records $(\mathrm{n}=$ 26-38) up to dry-off were included in analysis.

Bacteriology results of quarter foremilk secretions taken at dry-off were not available for cow treatment allocation. To account for potential bias in the level of potential IMI at dry-off in different treatment groups, a separate data set was generated (NoIMI) for each series of analyses, in which cows that had bacteria present in their foremilk at the time of treatment allocation were subsequently removed from the analyses; 11.5 and $10.2 \%$ of cow lactations were removed from the LowSCC ITS and AB+ITS data sets, respectively.

To assess the impact of our selection criteria on the results, 2 additional series of analyses were tested. Animal eligibility for classification as LowSCC was reassigned on the basis that SCC had not exceeded 150,000 cells $/ \mathrm{mL}$ and, in a separate series of analyses, had not exceeded 100,000 cells $/ \mathrm{mL}$ in the previous lactation. Cows that exceeded these thresholds were moved to the HighSCC treatment group for their respective analyses.

$S C C$ Variables. In addition to test-day SCS, the mean, minimum, and maximum SCS were quantified separately within cow-lactation for each analyzed period (i.e., first 3 records, first $120 \mathrm{~d}$, and all of lactation). Furthermore, we quantified the number of records with SCC >200,000 cells/mL within a cow-lactation for each studied period.

The effect of treatment (ITS, AB+ITS, or HighSCC) on mean, minimum, and maximum SCS was quantified using a repeatability linear mixed model in SAS (SAS Institute, 2017) and adjusted for the fixed effects of experimental treatment (of the concurrent trial), coefficients of heterosis and recombination, month of calving (January, February, March, April), parity (2, $3,4+)$, and year $(2015,2016,2017)$. The proportion of Holstein-Friesian, Jersey, and Norwegian Red were fitted as separate continuous variables; the "other" breed was not included to avoid linear dependency in the model. Initial analyses indicated a difference in milk yield across treatment groups; thus, average daily milk yield from the previous lactation was included as a continuous effect. Cow across year was included as a repeated effect. Model covariance structure was selected using Akaike's information criterion to compare the log-likelihood of alternative models with identical 
fixed effects. An autoregressive covariance structure with heterogeneous variance was fitted. Test-day SCS was analyzed using a similar model to the summary SCS traits, with cow included as a random effect and week of lactation as a repeated effect nested within cowlactation; an autoregressive covariance structure with compound symmetry was fitted. The effect of treatment on daily milk yield and weekly milk composition was quantified using the same model as test-day SCS, with the inclusion of days in milk as an explanatory variable when milk yield was the dependent variable and the inclusion of test-day SCS as an explanatory variable when either milk yield or composition were dependent variables. The effect of treatment on the number of records with high SCC (>200,000 cells/mL) was quantified using an ordinal regression model with a cumulative logit link function (Proc Genmod; SAS Institute, 2017) adjusted for the same fixed effects as the linear model to quantify summary SCS traits, with cow included as a repeated effect.

Individual Quarter SCC. The effect of treatment on quarter level SCS was analyzed by (1) considering each time point independently, and (2) considering samples taken at $2 \mathrm{wk}$ postcalving and at mid-lactation jointly. All models were adjusted for the fixed effects of experimental treatment (of the concurrent trial); proportion of Holstein-Friesian, Jersey, and Norwegian Red; coefficients of heterosis and recombination; month of calving (January, February, March, April); parity $(2,3,4+)$; year $(2015,2016,2017)$; and quarter (right front, right hind, left front, and left hind). Quarter samples that had SCC quantified using CMT were analyzed using ordinal regression with a cumulative logit link function (Proc Genmod, SAS Institute, 2017) and included the repeated effect of quarter nested with cow lactation. Samples taken at 2 wk postcalving and mid lactation were analyzed using a repeatability linear mixed model in SAS (SAS Institute, 2017) and included the repeated effect of quarter nested within cow lactation. When all time points were analyzed together, a repeatability model that included quarter treated as a repeated effect nested within time of sampling and cow lactation was tested.

Presence of Bacteria. Presence of bacteria was dichotomized as present or absent and analyzed using a logistic regression model (Proc Genmod; SAS Institute, 2017) adjusted for the same fixed effects as for the CMT analyses. Because of the smaller data set available for the bacteriology analyses, concurrent experimental treatment was replaced by experimental farm as an explanatory variable. Quarter was treated as a repeated effect nested within cow, year, and time of sampling.

\section{RESULTS}

The number of cow lactations and records included in each treatment group for analysis and their daily milk yield and fat and protein composition are shown in Table 1. The strict data-editing criteria used resulted in different treatment group sizes available for analyses; data were required to be recorded within 35 DIM (for inclusion in the "first 3 records" data set), and a minimum of 12 and 26 records per lactation were required for inclusion in the "first 120 DIM" and "full lactation" data sets, respectively. Of the 83 cows present in the herd for the $3 \mathrm{yr}$ of the study (only one herd participated for the entire study), 17 cows were classified as LowSCC across all $3 \mathrm{yr}$, whereas 13 cows were never classified as LowSCC.

Table 1. Number of cows, lactations, and records and least squares means (SE in parentheses) daily milk yield (kg) and weekly milk fat and protein percent within the first 3 records (early), up to 120 DIM (mid) and across lactation (full) ${ }^{1}$

\begin{tabular}{|c|c|c|c|c|c|c|}
\hline $\begin{array}{l}\text { Period and } \\
\text { treatment }\end{array}$ & Cows (no.) & $\begin{array}{l}\text { Lactations } \\
\text { (no.) }\end{array}$ & $\begin{array}{l}\text { Records } \\
\text { (no.) }\end{array}$ & Milk (kg) & Fat $(\%)$ & Protein (\%) \\
\hline \multicolumn{7}{|l|}{ Early } \\
\hline ITS & 141 & 160 & 366 & $22.28(0.49)^{\mathrm{A}}$ & $5.12(0.08)^{\mathrm{A}}$ & $3.61(0.03)^{\mathrm{A}}$ \\
\hline HighSCC & 284 & 342 & 793 & $21.84(0.44)^{\mathrm{A}}$ & $5.08(0.07)^{\mathrm{A}}$ & $3.59(0.03)^{\mathrm{A}}$ \\
\hline \multicolumn{7}{|l|}{ Mid } \\
\hline ITS & 145 & 163 & 2,377 & $23.69(0.31)^{\mathrm{A}}$ & $4.60(0.03)^{\mathrm{A}}$ & $3.55(0.01)^{\mathrm{A}}$ \\
\hline \multicolumn{7}{|c|}{ (2) } \\
\hline ITS & 142 & 159 & 5,348 & $24.75(0.22)^{\mathrm{A}}$ & $4.84(0.03)^{\mathrm{A}}$ & $3.84(0.01)^{\mathrm{A}}$ \\
\hline $\mathrm{AB}+\mathrm{ITS}$ & 132 & 154 & 5,166 & $24.09(0.22)^{\mathrm{B}}$ & $4.85(0.03)^{\mathrm{A}}$ & $3.85(0.01)^{\mathrm{A}}$ \\
\hline HighSCC & 287 & 341 & 11,248 & $24.15(0.20)^{\mathrm{B}}$ & $4.84(0.02)^{\mathrm{A}}$ & $3.83(0.01)^{\mathrm{A}}$ \\
\hline
\end{tabular}

\footnotetext{
$\overline{\mathrm{A}, \mathrm{B}}$ Means with different superscripts within a column and time period differed significantly at $P<0.001$.

${ }^{1}$ LowSCC cows did not exceed 200,000 cells/mL or present with clinical mastitis in the previous lactation; HighSCC cows exceeded 200,000 cells $/ \mathrm{mL}$ at least once or presented with clinical mastitis in previous lactation. LowSCC cows were treated with teat sealant alone (ITS) or with antibiotic plus teat sealant (AB+ITS); HighSCC cows were treated with AB+ITS.
} 
Cows administered AB+ITS had $0.67 \mathrm{~kg}$ (95\% CI: 0.35 to $0.93 \mathrm{~kg}$ ) lower daily milk yield than cows administered ITS alone when records from across the lactation were considered (Table 1). No differences in milk composition were observed across treatment groups (Table 1).

The percent of quarters identified with bacteria at different time points of lactation are presented in Table 2 for cows in all treatment groups. Staphylococcus aureus was the most prevalent pathogen among the populations included in this study and was identified at each time point in each treatment group (Table 2). With the exception of Escherichia coli, the listed pathogens were present across lactation in at least one treatment group.

\section{Composite SCC}

LowSCC cows administered AB+ITS at dry-off had lower test-day SCS in the first 3 records $(P=0.03)$, the first $120 \mathrm{~d}(P=0.003)$, and across the entire lactation $(P=0.003)$ relative to cows administered ITS alone (Table 3). We detected no difference in test-day SCS between HighSCC cows and either of the LowSCC treatment groups up to 120 DIM; however, test-day SCS was lower in the LowSCC AB+ITS group than in the HighSCC group when the entire lactation was considered $(P=0.01$; Table 3$)$. Mean, minimum, and maximum SCS were lower in the AB+ITS group than in the ITS group in early lactation $(P<0.05$; Table 3$)$. However, minimum SCS did not differ between groups later in lactation. Mean, minimum, and maximum SCS did not differ between cows administered ITS alone and HighSCC cows at any time point. Figure 1 shows the LSM test-day SCS of LowSCC cows in both the ITS and $\mathrm{AB}+\mathrm{ITS}$ treatment groups for each $50 \mathrm{~d}$ of lactation and indicates that the SCS of cows given ITS alone was significantly higher until d 250 of lactation, after which no difference was observed between the 2 groups.

The odds of cows administered ITS alone having an SCC reading $>200,000$ cells $/ \mathrm{mL}$ within the first 3 records and $120 \mathrm{~d}$ of lactation, respectively, was 2.9 (95\% CI: 1.2 to 7.0 ) and 3.0 (95\% CI: 1.6 to 5.8) times the odds of cows administered AB+ITS having an SCC reading of $>200,000$ cells $/ \mathrm{mL}$. In total, 19.5 and $9.1 \%$ of LowSCC cow lactations treated with ITS alone or with $\mathrm{AB}+\mathrm{ITS}$ and $19.1 \%$ of HighSCC cow lactations had an SCC reading $>200,000$ cells $/ \mathrm{mL}$ in the first 35 DIM; the percentage of records that exceeded 200,000 cells $/ \mathrm{mL}$ were $7.5,2.4$, and $9.7 \%$ for ITS, AB+ITS, and HighSCC groups, respectively. However at the end of lactation $(>239 \mathrm{~d}), 29.5,29.9$, and $45.2 \%$ of ITS, $\mathrm{AB}+\mathrm{ITS}$, and HighSCC cow lactations had had an SCC reading $>200,000$ cells $/ \mathrm{mL}$ (Figure 2 ).

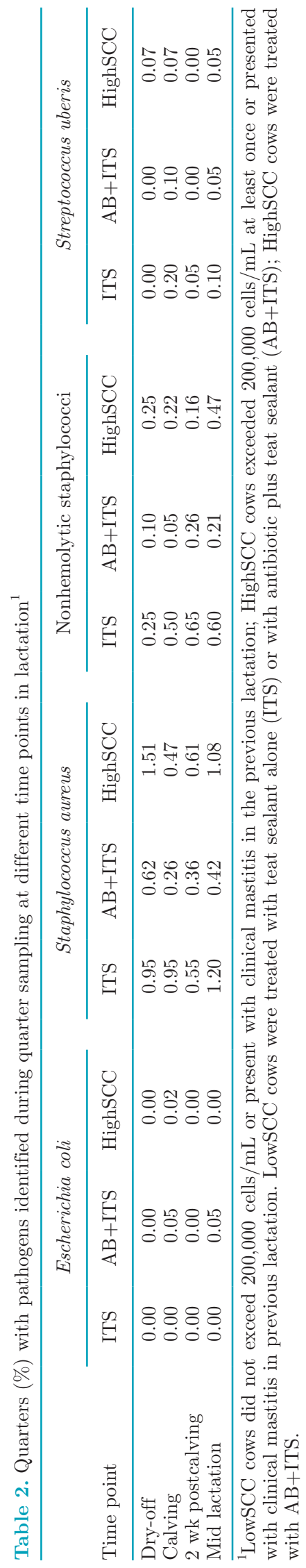


Table 3. Least squares means (SE in parentheses) of test-day SCS and lactation mean, minimum, and maximum SCS within the first 3 records (early), up to 120 DIM (mid), and across lactation (full) ${ }^{1}$

\begin{tabular}{|c|c|c|c|c|}
\hline \multirow{2}{*}{$\begin{array}{l}\text { Period and } \\
\text { treatment }\end{array}$} & \multicolumn{4}{|c|}{ SCS } \\
\hline & Test-day & Mean & Minimum & Maximum \\
\hline \multicolumn{5}{|l|}{ Early } \\
\hline ITS & $4.64(0.050)^{\mathrm{A}}$ & $4.66(0.049)^{\mathrm{A}}$ & $4.47(0.045)^{\mathrm{A}}$ & $4.83(0.059)^{\mathrm{A}}$ \\
\hline $\mathrm{AB}+\mathrm{ITS}$ & $4.55(0.051)^{\mathrm{B}}$ & $4.56(0.049)^{\mathrm{B}}$ & $4.40(0.046)^{\mathrm{B}}$ & $4.72(0.059)^{\mathrm{B}}$ \\
\hline HighSCC & $4.61(0.045)^{\mathrm{AB}}$ & $4.64(0.044)^{\mathrm{A}}$ & $4.46(0.041)^{\mathrm{A}}$ & $4.84(0.052)^{\mathrm{A}}$ \\
\hline \multicolumn{5}{|l|}{ Mid } \\
\hline ITS & $4.49(0.038)^{\mathrm{A}}$ & $4.50(0.038)^{\mathrm{A}}$ & $4.05(0.036)^{\mathrm{A}}$ & $5.14(0.066)^{\mathrm{A}}$ \\
\hline $\mathrm{AB}+\mathrm{ITS}$ & $4.38(0.040)^{\mathrm{B}}$ & $4.41(0.040)^{\mathrm{B}}$ & $4.00(0.038)^{\mathrm{A}}$ & $4.95(0.069)^{\mathrm{B}}$ \\
\hline HighSCC & $4.45(0.034)^{\mathrm{AB}}$ & $4.47(0.035)^{\mathrm{A}}$ & $4.04(0.033)^{\mathrm{A}}$ & $5.09(0.059)^{\mathrm{A}}$ \\
\hline \multicolumn{5}{|l|}{ Full } \\
\hline ITS & $4.62(0.034)^{\mathrm{A}}$ & $4.64(0.034)^{\mathrm{A}}$ & $3.99(0.034)^{\mathrm{A}}$ & $5.42(0.062)^{\mathrm{A}}$ \\
\hline $\mathrm{AB}+\mathrm{ITS}$ & $4.53(0.035)^{\mathrm{B}}$ & $4.56(0.034)^{\mathrm{B}}$ & $3.98(0.035)^{\mathrm{A}}$ & $5.24(0.064)^{\mathrm{B}}$ \\
\hline HighSCC & $4.59(0.031)^{\mathrm{A}}$ & $4.61(0.031)^{\mathrm{A}}$ & $3.99(0.031)^{\mathrm{A}}$ & $5.43(0.055)^{\mathrm{A}}$ \\
\hline
\end{tabular}

The LSM of SCS of all treatment groups was numerically lower in the NoIMI data set (Table 4) relative to the full data set (Table 3); however, the difference in mean, minimum, and maximum SCS between treatment groups did not change. There was no difference in the test-day SCS of LowSCC and HighSCC groups up to mid lactation in the full data set (Table 3); however, in the NoIMI data set, the test-day SCS of LowSCC cows treated with $\mathrm{AB}+\mathrm{ITS}$ was lower than that of HighSCC cows in the first 3 records, whereas the test-day SCS of LowSCC cows treated with ITS alone was higher than that of either group treated with antibiotics up to mid lactation (Table 4). In the NoIMI data set, cows administered ITS alone were 3.4 (95\% CI: 1.24 to 9.27) and 4.4 (95\% CI: 2.03 to 9.37) times more likely to have an SCC reading $>200,000$ cells $/ \mathrm{mL}$ within the first 3 records and within 120 DIM, respectively, relative to LowSCC cows treated with AB+ITS.

The proportion of cows eligible for inclusion in the experiment decreased from $48 \%$ to 38 and $25 \%$ when the threshold for inclusion in the LowSCC treatment groups decreased from a maximum previous lactation SCC reading of 200,000 cells/mL to 150,000 and 100,000 cells/mL, respectively. Regardless of the selection threshold imposed, LowSCC cows treated with ITS had higher SCS than LowSCC cows treated with AB+ITS (Table 5).

\section{Quarter-Level SCC and Bacteriology}

We found no difference in quarter-level SCS between quarters of cows treated with ITS alone or with AB+ITS. However, both of the LowSCC groups had lower quarter-level SCS at 120 DIM compared with that of the HighSCC group $(P<0.001)$.

Across lactation, $6.0 \%$ of quarters of LowSCC cows treated with ITS, $2.6 \%$ of quarters of LowSCC treated with $\mathrm{AB}+\mathrm{ITS}$, and $5.2 \%$ of quarters of HighSCC cows had bacteria present in the foremilk. The odds of LowSCC cows treated with ITS having bacteria present in their foremilk, therefore, was 2.7 (95\% CI: 1.91 to 3.85 ) and 1.6 (95\% CI: 1.22 to 2.03 ) times the odds of LowSCC cows treated with $\mathrm{AB}+\mathrm{ITS}$ and the odds of HighSCC cows treated with $\mathrm{AB}+\mathrm{ITS}$, respectively. Although cows treated with antibiotic at dry-off (both LowSCC and HighSCC cows) had a numerically lower incidence of Staphylococcus aureus and nonhemolytic staphylococci detected in their foremilk at calving relative to at drying-off, LowSCC cows treated with ITS only had numerically similar or increased levels of those pathogens detected after dry-off (Table 2). No difference in the type of bacteria present was detected between treatment groups.

\section{DISCUSSION}

Blanket dry-cow therapy historically formed part of a 5 -point plan to reduce mastitis; however, the substantial improvements in herd-level SCC observed in recent years (Berry et al., 2006) bring into question the current requirement for blanket therapy of all herds. Bulk tank SCC from the Irish national database showed an increase in the proportion of both herds and milk volume with an annual average SCC $<200,000$ cells/ $\mathrm{mL}$ from 39 to $62 \%$ and from 46 to $67 \%$, respectively, between 2013 and 2016 (AHI, 2018). Selective dry-cow 


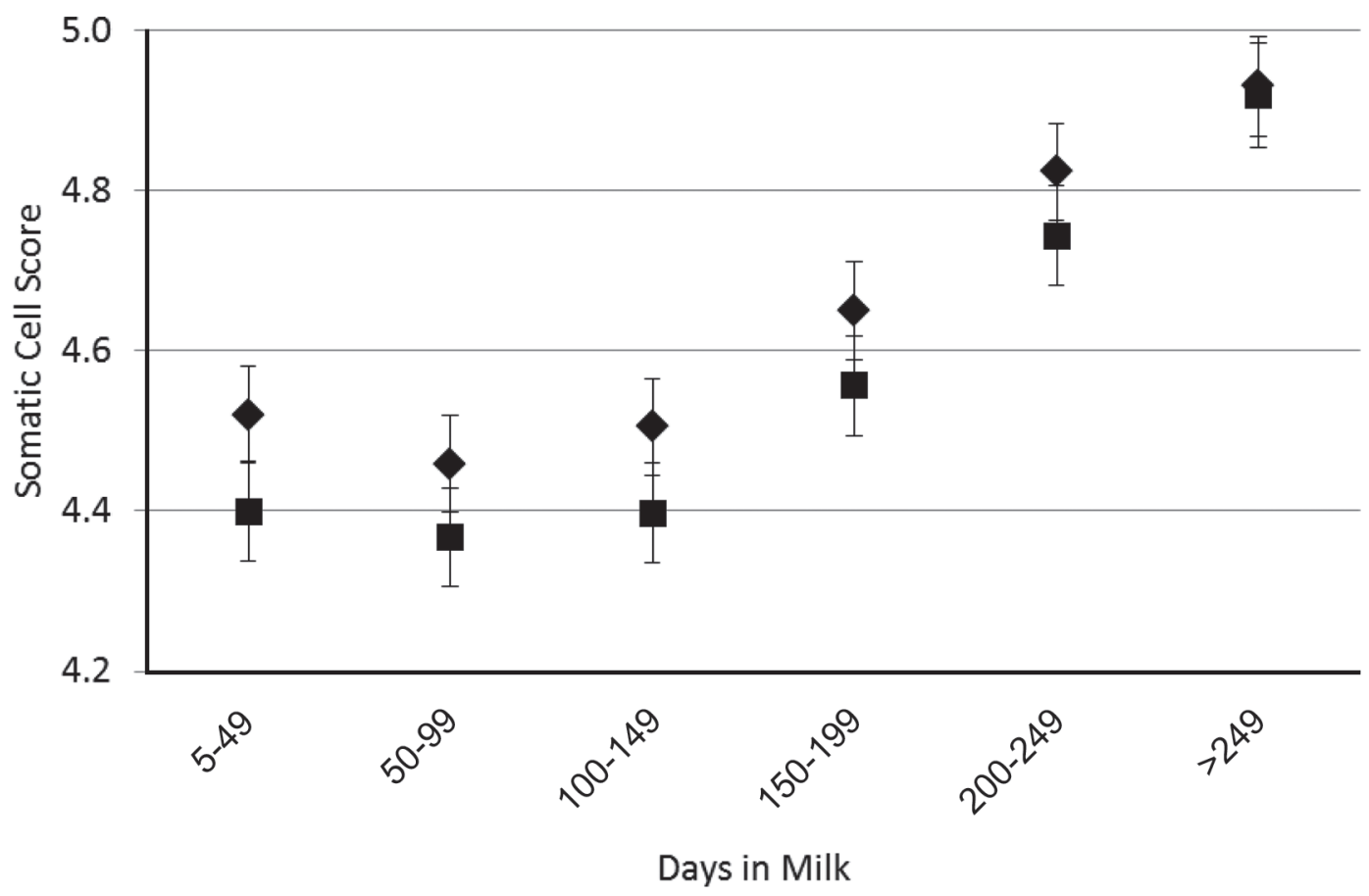

Figure 1. Least squares means SCS $( \pm 1.96 \mathrm{SE})$ of cows with historically low SCC subsequently treated with teat sealant alone $(\downarrow)$ or antibiotic plus teat sealant ( $\mathbf{\square})$ at drying-off across different stages of lactation.

therapy is a concept gaining ground in dairy production systems worldwide at varying rates. Vanhoudt et al. (2018) reported that, in 2015 (over 2 yr after the ban on preventative antimicrobials was issued to Dutch dairy farmers), a median of $55 \%$ of dry periods of 20 Dutch commercial herds studied did not have antimicrobials administered. However, dry-cow therapy coverage is estimated to be much higher in Irish dairy herds (More et al., 2017). Therefore, the objective of this study was to assess the potential for a selective dry-cow therapy program in Irish grazing dairy cows.

\section{Using Teat Sealant Alone to Control SCC}

Motivation for this study was drawn from the increasing public concern at the high level of antimicrobial use in our livestock industries and the potential to reduce the level of prophylactic antimicrobials used. Thus, the pertinent question for this study was the efficacy of teat sealant alone in place of antibiotic treatment plus teat sealant to prevent new infections. Few studies have reported this comparison. Bradley et al. (2010) administered teat sealant only or teat sealant plus antibiotic in ipsilateral quarters of 433 cows in 6 commercial herds in southwest England. Those authors found no difference between treatments in the likelihood of contracting mastitis up to 100 DIM. In the study of Bradley et al. (2010), the cow was her own control; however, quarter interdependency was accounted for through random allocation of treatment to either the left or right side. More recently, Vasquez et al. (2018) showed no difference in the cure rate or new infection rate of 611 cows treated with either teat sealant only or antibiotic plus teat sealant, although the teat sealant group tended to perform worse $(P=0.09)$. However, the study of Vasquez et al. (2018) used a single application of an external teat sealant, which is expected to offer less protection than a properly inserted internal teat sealant (Lim et al., 2007), as was used in the present study.

Using teat sealant alone compared with antibiotic plus teat sealant resulted in a reduction of the herd usage of dry-cow antimicrobials. Potentially $48 \%$ fewer cow-lactations required antimicrobials at drying-off in these research herds than if the traditional blanket therapy approach had been adopted (because of the randomization of treatment across the LowSCC cows, the reduction in lactations treated with dry-off antimicrobials was actually $24 \%$ ). However, cows that did not receive prophylactic treatment had a greater probability of an SCC exceeding 200,000 cells/mL during lactation. More et al. (2017) recently reported an inverse relationship between sales of antimicrobial tubes for lactation use and sales of antimicrobial tubes for dry-cow therapy over the same period in Ireland. Scherpenzeel et al. (2014) used a split-udder design, treating 2 quarters 
Table 4. Least squares means (SE in parentheses) of test-day, mean, minimum, and maximum SCS within the first 3 records (early), up to 120 DIM (mid), and across lactation (full) for cows that did not have bacteria present in their foremilk at dry-off ${ }^{1}$

\begin{tabular}{lcccc}
\hline & \multicolumn{3}{c}{ SCS } \\
\cline { 2 - 5 } $\begin{array}{l}\text { Period and } \\
\text { treatment }\end{array}$ & Test-day & Mean & Minimum & Maximum \\
\hline Early & $4.59(0.051)^{\mathrm{A}}$ & $4.60(0.049)^{\mathrm{A}}$ & $4.44(0.045)^{\mathrm{A}}$ & $4.77(0.061)^{\mathrm{A}}$ \\
ITS & $4.49(0.051)^{\mathrm{B}}$ & $4.51(0.049)^{\mathrm{B}}$ & $4.35(0.045)^{\mathrm{B}}$ & $4.66(0.062)^{\mathrm{B}}$ \\
AB+ITS & $4.59(0.047)^{\mathrm{A}}$ & $4.61(0.045)^{\mathrm{A}}$ & $4.44(0.042)^{\mathrm{A}}$ & $4.80(0.057)^{\mathrm{A}}$ \\
HighSCC & & & & \\
Mid & $4.46(0.033)^{\mathrm{A}}$ & $4.47(0.040)^{\mathrm{A}}$ & $4.02(0.038)^{\mathrm{A}}$ & $5.11(0.072)^{\mathrm{A}}$ \\
ITS & $4.38(0.034)^{\mathrm{B}}$ & $4.37(0.041)^{\mathrm{B}}$ & $3.96(0.040)^{\mathrm{A}}$ & $4.90(0.074)^{\mathrm{B}}$ \\
AB+ITS & $4.37(0.031)^{\mathrm{B}}$ & $4.46(0.038)^{\mathrm{A}}$ & $4.01(0.036)^{\mathrm{A}}$ & $5.11(0.067)^{\mathrm{A}}$ \\
HighSCC & & & & \\
Full & $4.59(0.031)^{\mathrm{A}}$ & $4.61(0.035)^{\mathrm{A}}$ & $3.96(0.035)^{\mathrm{A}}$ & $5.39(0.067)^{\mathrm{A}}$ \\
ITS & $4.51(0.032)^{\mathrm{B}}$ & $4.53(0.036)^{\mathrm{B}}$ & $3.94(0.036)^{\mathrm{A}}$ & $5.19(0.068)^{\mathrm{B}}$ \\
AB+ITS & $4.59(0.029)^{\mathrm{A}}$ & $4.59(0.033)^{\mathrm{A}}$ & $3.96(0.033)^{\mathrm{A}}$ & $5.48(0.062)^{\mathrm{A}}$ \\
HighSCC & &
\end{tabular}

$\overline{\mathrm{A}, \mathrm{B}}$ Means with different superscripts within a column and time period differed significantly at $P<0.05$.

${ }^{1}$ LowSCC cows did not exceed 200,000 cells/mL or present with clinical mastitis in the previous lactation; HighSCC cows exceeded 200,000 cells/mL at least once or presented with clinical mastitis in previous lactation. LowSCC cows were treated with teat sealant alone (ITS) or with antibiotic plus teat sealant (AB+ITS); HighSCC cows were treated with AB+ITS.

with antibiotic and leaving 2 quarters untreated, to investigate the potential that reducing prophylactic antimicrobial treatment at dry-off results in increased use of therapeutic antimicrobials. However, those authors found that antibiotic use related to mastitis was reduced by $85 \%$ in quarters treated only therapeutically.
Most studies that have investigated the use of antibiotic treatment at drying off are limited to early (Golder et al., 2016) or mid subsequent lactation (Sampimon et al., 2009; Bradley et al., 2010; Cameron et al., 2014; Wittek et al., 2018) only. Yet results from this study show that cows treated with antibiotic plus teat seal-
ITS

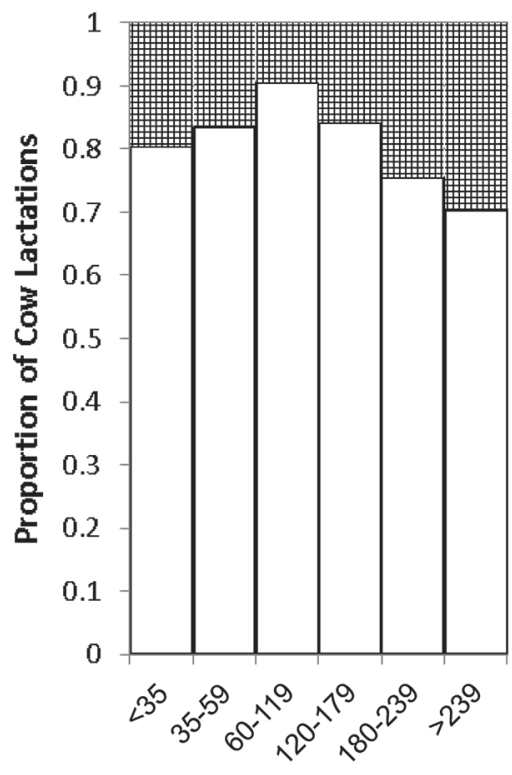

$A B+I T S$

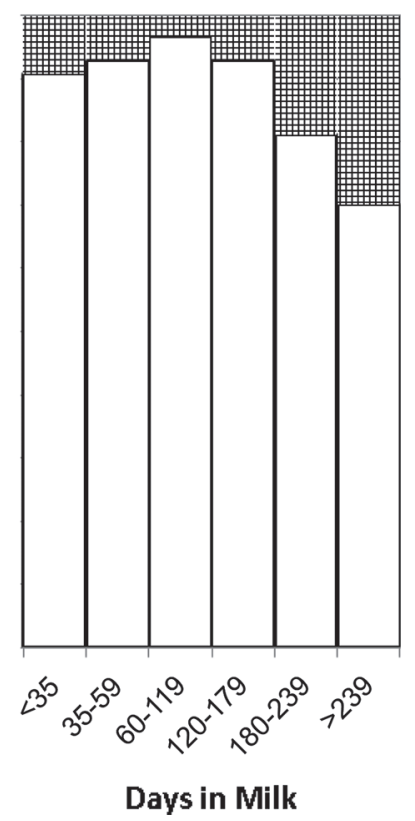

HighSCC

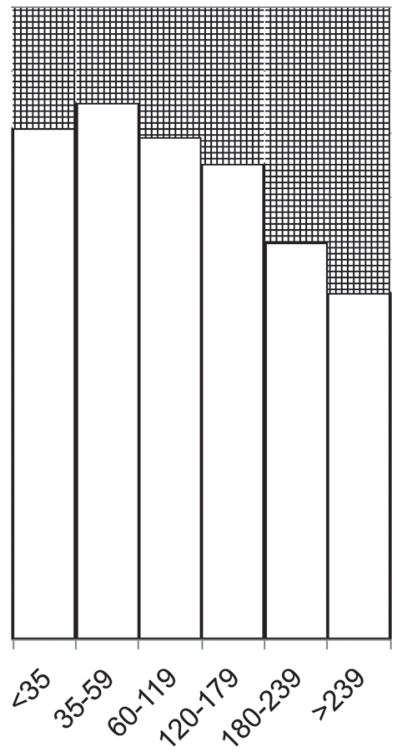

Figure 2. The proportion of cow lactations with an SCC reading $>200,000$ cells $/ \mathrm{mL}$ (shaded area) across days in milk when treated with internal teat sealant alone (ITS) or antibiotic plus teat sealant (AB+ITS), or when treated with AB+ITS because of a high SCC record in the previous lactation (HighSCC). 
Table 5. Least squares means of test-day SCS (back transformed SCC in parentheses) within the first 3 records (early), up to 120 DIM (mid), and across lactation (full) when only cows that had not exceeded 200,000 cells/mL (SCC200), 150,000 cells/mL (SCC150) or 100,000 cells/mL (SCC100) in the previous lactation were included $^{1}$

\begin{tabular}{lccc}
\hline $\begin{array}{l}\text { Period and } \\
\text { treatment }\end{array}$ & SCC200 & SCC150 & SCC100 \\
\hline $\begin{array}{l}\text { Early } \\
\text { ITS }\end{array}$ & $4.639(43,530)^{\mathrm{A}}$ & $4.637(43,330)^{\mathrm{A}}$ & $4.637(43,380)^{\mathrm{A}}$ \\
AB+ITS & $4.546(35,155)^{\mathrm{B}}$ & $4.519(33,006)^{\mathrm{B}}$ & $4.501(31,658)^{\mathrm{B}}$ \\
Mid & $4.488(30,746)^{\mathrm{A}}$ & $4.486(30,626)^{\mathrm{A}}$ & $4.501(31,709)^{\mathrm{A}}$ \\
ITS & $4.384(24,232)^{\mathrm{B}}$ & $4.375(23,718)^{\mathrm{B}}$ & $4.353(22,562)^{\mathrm{B}}$ \\
AB+ITS & $4.618(41,523)^{\mathrm{A}}$ & $4.588(38,743)^{\mathrm{A}}$ & $4.603(40,104)^{\mathrm{A}}$ \\
Full & $4.532(34,001)^{\mathrm{B}}$ & $4.505(31,981)^{\mathrm{B}}$ & $4.491(31,002)^{\mathrm{B}}$ \\
ITS & & & \\
AB+ITS & & & \\
${ }^{\mathrm{A}, \mathrm{B}}$ Means with different superscripts within a column and time period denote statistical significance at $P<$ \\
${ }^{0.05 .}$
\end{tabular}

ant at dry-off had lower SCS throughout lactation than cows treated with teat sealant only. The most frequent pathogen isolated from the quarters of cows in the present study was Staph. aureus (Table 2), a contagious pathogen that is shed cyclically and therefore difficult to detect using the timed quarter sampling procedure outlined in this study. Nonetheless, Staph. aureus is known to persist into lactation (Roberson et al., 1994) and was detected across lactation in the quarters of cows in all treatment groups. Herds with contagious pathogens such as Staph. aureus present also benefit indirectly from antibiotic treatment through reduced exposure of other animals or quarters of the same animal to the pathogen (Barkema et al., 2006). In the present study, however, all cows - whether treated with or without antibiotic - were managed together. Further work is required to uncover the mechanism by which antibiotic dry-cow therapy protects treated animals late into lactation.

\section{Selective Dry-Cow Therapy and Herd-Level SCC}

Results from this study showed that prophylactic antibiotic treatment at dry-off does reduce SCC across the subsequent lactation and reduces the likelihood of having high SCC up to mid-lactation. However, the SCC and infection rate (as assumed from the incidence of high SCC) of the herds that operated selective drycow therapy in the present study were not problematic; the back-transformed SCC of LowSCC cows treated with ITS alone or treated with AB+ITS were 41,523 and 34,001 cells $/ \mathrm{mL}$, respectively (Table 3; Table 5). The unadjusted, untransformed mean SCC across lactation of the ITS and AB+ITS cows were 80,990 and 60,483 cells/mL, respectively. Additionally, the results of the current study show that the proportion of cows with SCC that exceeded 200,000 cells/mL at the end of lactation was similar for LowSCC cows treated with ITS alone and LowSCC cows treated with $\mathrm{AB}+\mathrm{ITS}$, whereas a higher proportion of HighSCC cows had SCC that exceeded 200,000 cells $/ \mathrm{mL}$ at the end of lactation (Figure 2). Bulk tank SCC readings from all herds remained below 200,000 cells/mL throughout the majority of the study (Figure 3). Because of the seasonal nature of dairy production on the majority of Irish dairy herds, SCC trends follow a seasonal pattern, with higher SCC found at the start of the year, coinciding with calving, early lactation, and indoor housing, and again at the end of the year, coinciding with dry-off, low milk yields, and indoor housing (McParland et al., 2013; O'Connell et al., 2015). The bulk tank arithmetic mean SCC of research herds involved in this study followed this expected seasonal pattern and exceeded 200,000 cells/mL only at initiation of lactation and dryoff (Figure 3).

\section{Milk Production}

Despite the observed reduction in SCS associated with antibiotic treatment and the known negative association between SCC and milk yield (Deluyker et al., 1993), cows treated with AB+ITS produced 0.67 $\mathrm{kg}$ milk less per day (2.7\% of daily yield) compared with cows treated with ITS alone in the present study (Table 1). Borm et al. (2006) found no difference in the milk yield of heifers within the first 200 DIM, whether treated with antibiotic and external teat sealant or external teat sealant only. However, they did report a significant herd $\times$ treatment interaction, whereby heifers treated with teat sealant had higher milk yield than 


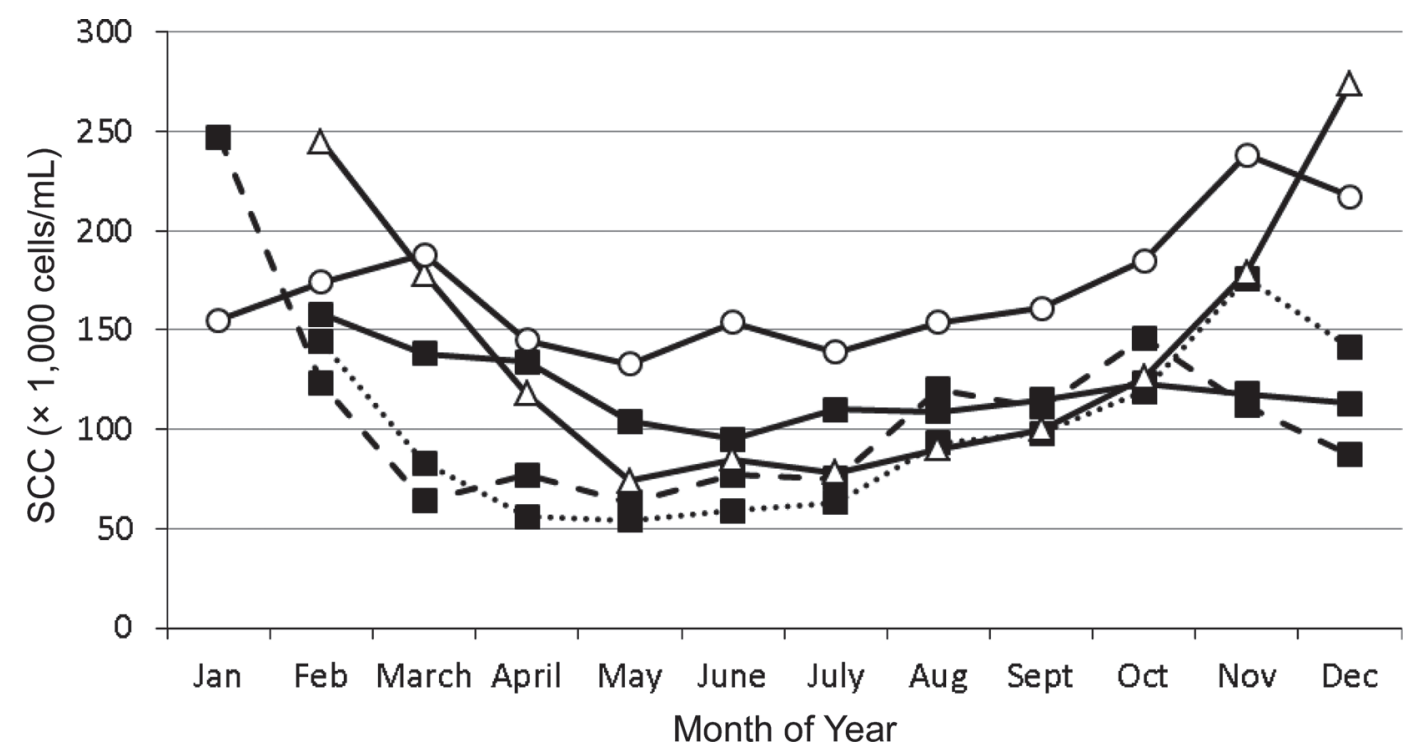

Figure 3. Bulk tank arithmetic SCC $(\times 1,000$ cells $/ \mathrm{mL})$ of the 3 research herds for each month of the year across the 3 yr of the study. Individual herds are distinguished by unique markers: Moorepark $(\bigcirc)$, Curtins $(\Delta)$, Clonakilty $(\boldsymbol{\square})$; herd years are distinguished by unique line style: 2015 (dotted line), 2016 (dashed line), 2017 (solid line).

those treated with antibiotic in only 5 of the 9 herds enrolled in the study, corroborating results from this study. However, the pathogens involved, as well as the timing of IMI, differ between heifers and older cows (Pyörälä and Taponen, 2009). Vasquez et al. (2018) documented a numerically higher milk yield $(P=0.20)$ across the first 26 DIM in cows treated with teat sealant only compared with cows treated with antibiotic and teat sealant. Differences in milk yield were only detected later in lactation in the present study (Table 1). In contrast, Wittek et al. (2018) reported that cows who received antibiotics at drying-off yielded 91 $\mathrm{kg}$ more milk than untreated cows in the subsequent lactation. However, Wittek et al. (2018) did not report on the use of teat sealants in their study population, although the use of teat sealants in their population was expected to be limited. Differences in the effect of antibiotic treatment on subsequent milk yield across studies may be influenced by the underlying pathogens that the antibiotic was treating.

\section{Animal Identification for Treatment Allocation}

Milk test-day SCC records and recorded mastitis incidences are useful for identifying animals for drycow treatment, as first reported by Vasquez et al. (2018). Although the present study demonstrated no difference in the test-day SCS of LowSCC cows treated with teat sealant only and HighSCC cows (cows with a high SCC or an incidence of mastitis in the previous lactation; Table 3), bacteria were identified at dry-off (after animals were assigned treatment) in the quarters of $28 \%$ of HighSCC cow lactations compared with $12 \%$ of LowSCC cow lactations.

Using milk recording data for use in selective drycow therapy adds another dimension (at no additional charge) to the benefits of routine milk recording. In Ireland, milk recording participation remains low, with less than $50 \%$ of Irish dairy cows participating in milk recording in 2016. Because the cost saving from reduced antibiotic purchase could form a large portion of the cost of milk recording (approximately $25 \%$ if milk recording 8 times per lactation), this new use of standard milk recording data further improves its attractiveness. Weekly milk recording data were available in the present study, but this is not likely to be feasible in commercial herds, with the exception of robotic milking herds. Further work is required to identify the optimal number and timing of test-days to best identify low-SCC candidates. The cut-off for testday results included in the categorization of cows as eligible for the present experiment was 4 to 6 wk before dry-off because of the increased SCC observed in lowyielding cows as they approach dry-off (Auldist et al., 1995). It has been suggested to use at least one record within $90 \mathrm{~d}$ of drying off to identify cows more likely to contract mastitis in the periparturient period (Green et al., 2007). Gohary and McDougall (2018) found that 
a single herd test in late lactation was as useful as multiple tests across the lactation as a predictor of IMI at drying-off.

An SCC threshold of 200,000 cells/mL is commonly used to differentiate between high- and low-SCC animals (Schukken et al., 2003) and was used in the present study to indicate the potential for clinical mastitis and IMI. A high SCC threshold, rather than reported cases of clinical mastitis, was used in the present study because (1) weekly records of SCC were available for all animals, and (2) the research herds operated a mastitis detection protocol that used (in conjunction with on-farm symptom detection) weekly SCC records to identify and quarter sample high-SCC cows to determine the need for treatment and the appropriate treatment to be used. This early-warning system likely reduces the incidence of clinical mastitis below what might otherwise be expected. Recently, a document produced by the Royal Dutch Veterinary Association in the Netherlands to guide the use of antimicrobials at dry-off (KNMvD, 2014; summarized by Vanhoudt et al., 2018) recommended treatment of primiparous and multiparous cows with antimicrobials if SCC exceeded 150,000 and 50,000 cells $/ \mathrm{mL}$, respectively, in the last milk recording (within 6 wk of drying off). Ruegg (2016) developed a decision tree for selective dry-cow therapy based on both herd- and cow-level criteria. To apply a selective dry-cow therapy, the herd-level bulk SCC has to be $<250,000$ cells $/ \mathrm{mL}$ and both monthly cow SCC tests and clinical mastitis records are required. The cow-level criteria are that SCC has to be $<200,000$ cells/mL, no clinical case of mastitis in the last $90 \mathrm{~d}$ of lactation, and all quarters present with a CMT of $<2$.

Cows treated with ITS alone had higher SCS than cows treated with $\mathrm{AB}+\mathrm{ITS}$ when the SCC threshold for inclusion in the LowSCC group was decreased to 150,000 or 100,000 cells $/ \mathrm{mL}$. However, with the lower SCC thresholds, the number of cows included LowSCC, and thus available for ITS alone treatment, was decreased; therefore, the higher threshold of 200,000 cells / $\mathrm{mL}$ would result in less use of antimicrobials in the herd with little effect on the SCC of the herd (Table 5).

\section{CONCLUSIONS}

Milk recording data and recording of clinical cow mastitis cases are required to identify candidates suitable to receive antibiotic-free teat sealant during dry-off. In the present study, dry-cow therapy using teat sealant alone compared with antibiotic plus teat sealant resulted in higher SCC in the subsequent lactation; however, this increase in SCC was not large, indicating the potential for use of teat seal alone in low-SCC cows in herds with good mastitis control programs. This experiment should be replicated on commercial dairy farms.

\section{ACKNOWLEDGMENTS}

The authors thank all farm staff and technicians involved in this study for their contributions. Financial support from the Dairy Research Ireland Dairy Levy Trust is gratefully acknowledged.

\section{REFERENCES}

Animal Health Ireland. 2018. CellCheck: Briefing document 2018. Accessed Mar. 6, 2019. http://animalhealthireland.ie/wp-content/ uploads/2018/01/CellCheck-Briefing-Document-2018-FINAL.pdf.

Auldist, M. J., S. Coats, G. L. Rogers, and G. H. McDowell. 1995 Changes in the composition of milk from healthy and mastitic dairy cows during the lactation cycle. Aust. J. Exp. Agric. 35:427436.

Barkema, H. W., Y. H. Schukken, and R. N. Zadoks. 2006. Invited review: The role of cow, pathogen, and treatment regimen in the therapeutic success of bovine Staphylococcus aureus mastitis. J. Dairy Sci. 89:1877-1895.

Berry, D. P., B. O'Brien, E. J. O'Callaghan, K. O. Sullivan, and W. J. Meaney. 2006. Temporal trends in bulk tank somatic cell count and total bacterial count in Irish dairy herds during the past decade. J. Dairy Sci. 89:4083-4093.

Borm, A. A., L. K. Foz, K. E. Leslie, J. S. Hogan, S. M. Andrew, K. M. Moyes, S. P. Oliver, Y. H. Schukken, D. D. Hancock, C. T. Gaskins, W. E. Owens, and C. Norman. 2006. Effects of prepartum intramammary antibiotic therapy on udder health, milk production and reproductive performance in dairy heifers. J. Dairy Sci. 89:2090-2098.

Bradley, A. J., J. E. Breen, B. Payne, P. Williams, and M. J. Green. 2010. The use of a cephalonium containing dry cow therapy and an internal teat sealant, both alone and in combination. J. Dairy Sci. 93:1566-1577.

Cameron, M., S. L. McKenna, K. A. MacDonald, I. R. Dohoo, J. P. Roy, and G. P. Keefe. 2014. Evaluation of selective dry cow treatment following on-farm culture: Risk of postcalving intramammary infection and clinical mastitis in the subsequent lactation. J. Dairy Sci. 97:270-284.

Deluyker, H. A., J. M. Gay, and L. D. Weaver. 1993. Interrelationships of somatic cell count, mastitis, and milk yield in a low somatic cell count herd. J. Dairy Sci. 76:3445-3452.

Ferronatto, J. A., T. C. Ferronatto, M. Schneider, L. F. Pessoa, M. G. Blagitz, M. B. Heinemann, A. M. M. P. Della Libera, and F. N. Souza. 2018. Diagnosing mastitis in early lactation: Use of Somaticell, California mastitis test and somatic cell count. Ital. J. Anim. Sci. 17:723-729.

Gohary, K., and S. McDougall. 2018. Predicting intramammary infection status at drying off using indirect testing of milk samples. N. Z. Vet. J. 66:312-318.

Golder, H. M., A. Hodge, and I. J. Lean. 2016. Effects of antibiotic dry-cow therapy and internal teat sealant on milk somatic cell counts and clinical and subclinical mastitis in early lactation. J. Dairy Sci. 99:7370-7380.

Green, M. J., A. J. Bradley, G. F. Medley, and W. J. Browne. 2007. Cow, farm, and management factors during the dry period that determine the rate of clinical mastitis after calving. J. Dairy Sci. 90:3764-3776.

Heringstad, B., G. Klemetsdal, and J. Ruane. 2000. Selection for mastitis resistance in dairy cattle: a review with focus on the situation in the Nordic countries. Livest. Prod. Sci. 64:95-106.

Lim, G. H., K. E. Leslie, D. F. Kelton, T. F. Duffield, L. L. Timms, and R. T. Dingwell. 2007. Adherence and efficacy of an external 
teat sealant to prevent new intramammary infections in the dry period. J. Dairy Sci. 90:1289-1300.

McParland, S., B. O'Brien, and J. McCarthy. 2013. The association between herd- and cow- level factors and somatic cell count of Irish dairy cows. Ir. J. Agric. Food Res. 52:151-158.

Meaney, W. T. 1977. Effect of a dry period teat sealant on bovine udder infection. Ir. J. Agric. Food Res. 16:293-299.

More, S. J., T. A. Clegg, and F. McCoy. 2017. The use of national-level data to describe trends in intramammary antimicrobial usage on Irish dairy farms from 2003 to 2015. J. Dairy Sci. 100:6400-6413.

O'Connell, A., S. McParland, P. L. Ruegg, B. O'Brien, and D. Gleeson. 2015. Seasonal trends in milk quality in Ireland between 2007 and 2011. J. Dairy Sci. 98:3778-3790.

Paulrud, C. O. 2005. Basic concepts of the bovine teat canal. Vet. Res. Commun. 29:215-245.

Prestinaci, F., P. Pezzotti, and A. Pantosti. 2015. Antimicrobial resistance: A global multifaceted phenomenon. Pathog. Glob. Health 109:309-318.

Pyörälä, S., and S. Taponen. 2009. Coagulase-negative staphylococciemerging mastitis pathogens. Vet. Microbiol. 134:3-8.

Rabiee, A. R., and I. J. Lean. 2013. The effect of internal teat sealant products (Teat sealant and Orbeseal) on intramammary infection, clinical mastitis, and somatic cell counts in lactating dairy cows: A meta-analysis. J. Dairy Sci. 96:6915-6931.

Roberson, J. R., L. K. Fox, D. D. Hancock, J. M. Gay, and T. E. Besser. 1994. Ecology of Staphylococcus aureus isolated from various sites on dairy farms. J. Dairy Sci. 77:3354-3364.

Ruegg, P. L. 2016. Selecting herds and cows for selective dry cow therapy (video). Accessed Mar. 6, 2019. https://www.youtube.com/ watch? $\mathrm{v}=997 \mathrm{GZFWwJ0A}$

SAS Institute. 2017. Users' guide version 9.4: Statistics. SAS Institute Inc., Cary, NC.
Sampimon, O. C., S. De Vliegher, H. W. Barkema, J. Sol, and T. J. Lam. 2009. Effect of prepartum dry cow antibiotic treatment in dairy heifers on udder health and milk production. J. Dairy Sci. 92:4395-4403.

Schalm, O. W., and D. O. Noorlander. 1956. California Mastitis Test. Rhinehart Development Corp. Dairy Research Product Inc., Spencerville, IN. Accessed Jul. 30, 2018. http://www .rhinehartdevelopment.com/development/content/animal_health/ files/CMT\%20Test\%20Brochure.pdf.

Scherpenzeel, C. G. M., I. E. M. den Uijl, G. van Schaik, R. G. M. Olde Riekerink, J. M. Keurentjes, and T. J. G. M. Lam. 2014 Evaluation of the use of dry cow antibiotics in low somatic cell count cows. J. Dairy Sci. 97:3606-3614.

Schukken, Y. H., D. J. Wilson, F. Welcome, L. Garrison-Tikofsky, and R. N. Gonzalez. 2003. Monitoring udder health and milk quality using somatic cell counts. Vet. Res. 34:579-596.

Vanhoudt, A., K. van Hees-Huijps, A. T. M. van Knegsel, O. C. Sampimon, J. C. M. Vernooij, M. Nielen, and T. van Werven. 2018. Effects of reduced intramammary antimicrobial use during the dry period on udder health in Dutch dairy herds. J. Dairy Sci. 101:3248-3260.

VanRaden, P. M., and A. H. Sanders. 2003. Economic merit of crossbred and purebred US dairy cattle. J. Dairy Sci. 86:1036-1044.

Vasquez, A. K., D. V. Nydam, C. Foditsch, M. Wieland, R. Lynch, S. Eicker, and P. D. Virkle. 2018. Use of a culture-independent on-farm algorithm to guide the use of selective dry-cow antibiotic therapy. J. Dairy Sci. 101:5345-5361.

Wittek, T., A. Tichy, B. Grassauer, and C. Egger-Danner. 2018. Retrospective analysis of Austrian health recording data of antibiotic or nonantibiotic dry-off treatment on milk yield, somatic cell count, and frequency of mastitis in subsequent lactation. J. Dairy Sci. 101:1456-1463 